Hydrol. Earth Syst. Sci. Discuss., https://doi.org/10.5194/hess-2017-512

Manuscript under review for journal Hydrol. Earth Syst. Sci.

Discussion started: 17 August 2017

\title{
Frequently used drought indices reflect different drought conditions on global scale
}

\author{
Niko Wanders ${ }^{1,2}$, Anne F. Van Loon ${ }^{3}$, and Henny A.J. Van Lanen ${ }^{4}$ \\ ${ }^{1}$ Department of Civil and Environmental Engineering, Princeton University, Princeton, NJ, USA \\ ${ }^{2}$ Department of Physical Geography, Utrecht University, Utrecht, The Netherlands \\ ${ }^{3}$ School of Geography, Earth \& Environmental Sciences, University of Birmingham, United Kingdom \\ ${ }^{4}$ Hydrology and Quantitative Water Management Group, Wageningen University, The Netherlands \\ Correspondence to: N. Wanders (n.wanders@uu.nl)
}

\begin{abstract}
Drought is an abnormal and prolonged deficit in available water. Possible drought impacts are crop losses, famine, fatalities, power blackouts and degraded ecosystems. These severe socio-economic and environmental impacts show the need to carefully monitor drought conditions using a suitable index. Our objective is to provide an intercomparison of frequently used physical drought indices to show to which degree they are interchangeable for monitoring drought in precipitation, soil moisture, groundwater and streamflow. Physical indices are commonly introduced to predict drought impacts, because appropriate drought impact indices are still missing. Correlations $(R)$ between frequently used indices for different drought types were calculated at the global scale. We have made the index timeseries available to the community for future studies. Precipitation drought indices show low to intermediate correlations (ranging from $R=0.1$ to 0.75 ), soil moisture drought indices show an even lower similarity $(R=0.25)$. Indices for streamflow drought show the highest correlation $(R=0.5$ to 0.95$)$. Additionally, meteorological drought indices do not capture the soil moisture drought correctly ( $R=0.0$ to 0.6 ) nor streamflow drought ( $R=0.0$ to 0.7 ). These findings have implications for drought monitoring systems: (i) for each drought type, a different index should carefully be identified; (ii) drought indices that are designed to monitor the same drought type show large discrepancies in their anomalies and hence drought detection; (iii) there is no single superior physical drought index that is capable of accurately capturing the diverse set of drought impacts in all parts of the hydrological cycle.
\end{abstract} Keywords:Drought, Drought indices, Global, Climate, Soil moisture, Hydrology

\section{Introduction}

Drought is an abnormal and prolonged deficit in the available water and has a major impact on both natural and social hydrological resources (Wilhite, 2000; Tallaksen and Van Lanen, 2004; Mishra and Singh, 2010; Sheffield and Wood, 2011). Due to the large spatial and long temporal extent of drought events, they tend to have a large economic damage. The United states suffered an estimated agricultural loss of $\$ 5.5$ billion for the 2012-2014 California drought alone (Howitt et al., 2014, 2015; Medellín-Azuara et al., 2016). This drought was caused by lack of precipitation and snow accumulation in three consecutive years, leading to a significant reduction of the water levels in some of the major rivers and reservoirs affecting water security 
Hydrol. Earth Syst. Sci. Discuss., https://doi.org/10.5194/hess-2017-512

Manuscript under review for journal Hydrol. Earth Syst. Sci.

Discussion started: 17 August 2017

(c) Author(s) 2017. CC BY 4.0 License.

and energy production. Agriculture is even more heavily impacted resulting in job loss for an estimated 42800 agricultural workers (Howitt et al., 2014, 2015; Medellín-Azuara et al., 2016).

This example clearly shows that drought can affect all parts of the hydrological cycle and can propagate from precipitation, particularly snow in the mountains, to soil moisture and eventually to discharge anomalies. Three major drought types are identified that refer to different components of the hydrological cycle, namely, meteorological, soil moisture/agricultural and hydrological drought (Wilhite and Glantz, 1985). Depending on the type of drought the impacts on society and nature are different (Figure 1). This emphasizes the need to monitor drought throughout the hydrological cycle, to be able to pro-actively respond to all possible impacts. Bachmair et al. (2016a) call for indices that are meaningful for drought impact assessments. However, explicit drought impact indices (e.g. crop yield loss, cargo reduction of water-borne transport, reduction of electricity production, lower ecosystem services) hardly exists. Alternatively, physical indices have been linked to drought impacts. For example, meteorological indices to drought impacts (Stagge et al., 2015; Blauhut et al., 2015, 2016) and forest fires (Gudmundsson et al., 2014), or to water scarcity indicators (Pedro-Monzonía et al., 2015). We argue in this paper that the right physical drought index needs to be identified to a specific drought impact to improve predictability of the impacts.

Most drought indices aim to subtract the normal seasonal variation in water availability or water state from the climatological variations and thereby quantify extreme events and thus drought. However, the difference in the drought calculation for the different drought indices (e.g. Keyantash and Dracup, 2002) results in uncertainty of which indices could be used under a given circumstance and for what affected sector. It is obvious that this will lead to confusion about what kind of index is to be used for a given impact. Expert knowledge is required to monitor drought with the correct index. Mostly, the focus of drought monitoring is put on precipitation and soil moisture drought while the impact of drought on various sectors goes beyond these domains of the hydrological cycle (Figure 1). There are other metrics that are more specifically related to monitoring reservoir levels, aquifer levels, deliveries of water to users, and the fraction of water demand that can be met. These metrics are often not monitored in operational systems since they are site-specific, user dependent and only available at local scales (e.g. river basins or reservoirs). The World Meteorological Organization (WMO) recommended the use of a more general index that derives drought conditions from anomalies in precipitation (World Meteorological Organization, 2009). However, WMO also states that a single precipitation derived index would not suffice to monitor drought conditions relevant to all possible impacted sectors. Another important effort is made by the National Drought Mitigation Center in the United States, to provide a weekly inventory of United States drought conditions. The maps that they produce are the result of a combination of drought indices (i.e. combined or composite index) that show the drought severity. This combined approach does take into account meteorological, soil moisture and discharge observations to estimate the drought conditions. A big advantage of this approach is that it combines all possible drought types. The European Drought Observatory (EDO) provides spatial information on their Combined Drought Index (CDI, Sepulcre-Canto et al., 2012). This index is derived from a combination of the Standardized Precipitation Index (SPI-3), soil moisture anomaly derived from the hydrological model LISFLOOD (SMA) and the fraction of absorbed photosynthetically active radiation (fAPAR) derived from remote sensing. EDO then uses three drought stages, namely the Watch, Warning and Alert Phases (Van Lanen, 2014). The meteorological SPI-3 is used to indicate a meteorological drought (Watch Phase), subsequently followed by a soil moisture drought (Warning Phase) and eventually the fAPAR will 
Hydrol. Earth Syst. Sci. Discuss., https://doi.org/10.5194/hess-2017-512

Manuscript under review for journal Hydrol. Earth Syst. Sci.

Discussion started: 17 August 2017

(c) Author(s) 2017. CC BY 4.0 License.

indicate a drought in the vegetation (Alert Phase).

Here we make an attempt to identify how physical drought indices capture the drought phenomena in different parts of the hydrological cycle, how these indices are capturing droughts within the different drought types (hence intrasubstitution), and the agreement between indices from different groups, from now on referred to as intersubstitution. We conduct the analysis on the global scale to cover climate differences using modelled data to provide the necessary input to compute the extensive suite of drought indices. Unfortunately, no consistent set of observations with high spatial coverage is available to do this analysis at continental and global scales. Moreover, the high-resolution data provided by the model allows us to assess the impact of the local climate of the correlation between drought indices. This will provide additional insight, as how we can determine meaningful indices for drought impact assessment at continental and global scales.

The objective of this study is to investigate: (i) intersubstitution of drought indices used for different drought types, (ii) intrasubstitution of drought indices used for the same drought type, and (iii) dependency of this intersubstitution and intrasubstitution on climatology. A conceptual hydrological model was used to simulate time series of hydrological variables to determine different drought indices. Time series of these indices were compared on a global scale.

\section{Material and methods}

\subsection{Hydrological model}

A conceptual hydrological model (Van Lanen et al., 2013) was used to simulate the catchment response to meteorological forcing. The model was used to simulate the hydrological cycle at a global scale with a resolution of $0.5^{\circ}$ for the period 19582001. The model incorporates snow, soil moisture and groundwater modules that enable the simulation of the hydrological response of the $0.5^{\circ}$ grid cell. Using a lumped approach, the model generates gridded time series of snow accumulation, soil moisture, groundwater and discharge. The precipitation, temperature and potential evapotranspiration data that are required as forcing were derived from the WATCH reanalysis dataset (Weedon et al., 2011). The conceptual model uses a fixed catchment parametrization which reflects a sandy-loam soil with an intermediate groundwater response time. The model has been successfully applied in previous studies (Van Lanen et al., 2013; Van Loon et al., 2014; Wanders and Van Lanen, 2015; Taufik et al., 2017). The conceptual model allows for isolation of the climatic signal from differences in catchment characteristics.

This allow to focus on differences between drought indices, only with respect to different climate types. For a more detailed description of the model the reader is referred to Van Lanen et al. (2013); Wanders and Van Lanen (2015).

\subsection{Sensitivity analysis}

A sensitivity analysis was done to assess the robustness of the model parametrization with respect to the generated time series of soil moisture, discharge and derived drought indices. The sensitivity analysis by Van Lanen et al. (2013) showed that hydrological drought characteristics derived from simulated discharge, did not change significantly with changes parametrization. However, here we evaluate the robustness of the model with respect to different drought indices. The sensitivity of the soil 
Hydrol. Earth Syst. Sci. Discuss., https://doi.org/10.5194/hess-2017-512

Manuscript under review for journal Hydrol. Earth Syst. Sci.

Discussion started: 17 August 2017

(c) Author(s) 2017. CC BY 4.0 License.

(c) (1)
Hydrology and

Earth System

Sciences

Discussions

\section{DROUGHT}

Type

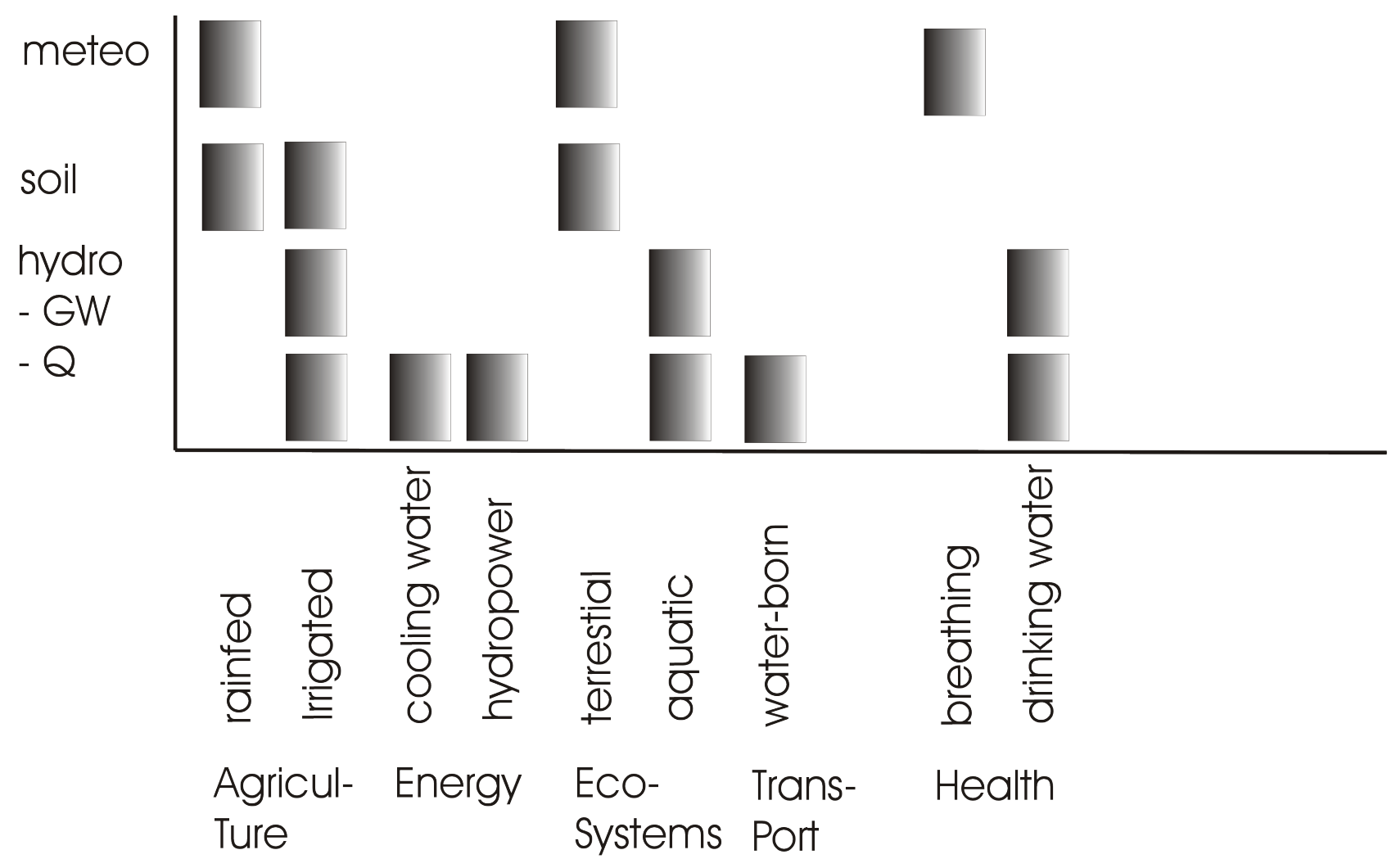

Figure 1. Different types of droughts and their impact on society and nature. meteo: meteorological drought, soil: soil water drought, and hydro-GW and hydro-Q refer to hydrological droughts in Groundwater (GW) and discharge (Q).

moisture and discharge simulations to changes in the parametrization was evaluated for a temperate climate (with seasonal snow impact). The relative difference in the variance and the mean of the soil moisture and discharge are related to the changes in parametrization. Thereafter, drought characteristics are calculated for different drought indices and the obtained timeseries are compared to a baseline scenario (sandy-loam soil with an intermediate groundwater response time). In order to assess the sensitivity of the model to the changes in the parametrization, we evaluated the correlation between the indices.

\subsection{Drought indices}

Drought in all parts of the hydrological cycle was evaluated using a selection of 10 frequently used drought indices, including the different lags resulting in a total of 20 indices (Table 1). These indices cover all drought types and strongly vary in calculation procedure and input data required, which were applied to detect drought conditions in the hydrological simulations. Here 
Hydrol. Earth Syst. Sci. Discuss., https://doi.org/10.5194/hess-2017-512

Manuscript under review for journal Hydrol. Earth Syst. Sci.

Discussion started: 17 August 2017

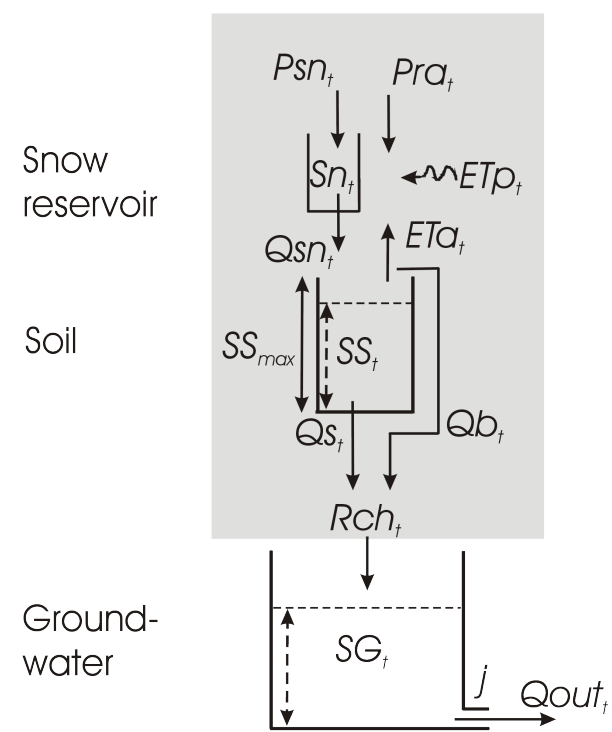

Figure 2. Model set-up of the synthetic hydrological model. The model consists of three partitions, Snow, Soil and Groundwater. $P_{s n}$ snowfall, $P_{r a}$ rainfall, $E T_{p}$ potential evapotranspiration, $E T_{a}$ actual evapotranspiration, $S_{n}$ snow storage, $S S$ soil storage, $S S_{\max }$ maximum soil storage, $Q_{s n}$ snow melt, $Q_{s}$ recharge to the groundwater from the unsaturated zone, $Q_{b}$ bypass flow, $R_{c h}$ total recharge to groundwater, $S G$ groundwater storage, $j$ groundwater response parameter, $Q_{\text {out }}$ groundwater discharge and $t$ is the time index.

Table 1. Indices under study and their properties. Input data refers to Precipitation $(P)$ and Potential Evapotranspiration $(P E T)$ derived from the WATCH reanalysis dataset and Snow $(S n)$, Soil Moisture $(S S)$, Groundwater $(S G)$ and Discharge $(Q)$ from the hydrological model

\begin{tabular}{llllll}
\hline Index & Type & Input data & Period (months) & Abbr. & Reference \\
\hline Effective Drought Index & Meteorological & $P$ & 12 & EDI & (Byun and Wilhite, 1999) \\
Standardized Precipitation Index & Meteorological & $P$ & $1,3,6,12,24$ & SPI & (McKee et al., 1993) \\
Standardized Prec. Evap. Index & Meteorological & $P, P E T$ & $1,3,6,12,24$ & SPEI & (Vicente-Serrano et al., 2009) \\
Palmer Drought Severity Index & Soil moisture & $P$ & - & PDSI & (Palmer, 1965) \\
Threshold level method & Meteorological & $P$ & 1 & MAP & (Yevjevich, 1967) \\
Threshold level method & Soil moisture & $S S$ & 1 & MAS & (Yevjevich, 1967) \\
Threshold level method & Hydrological & $Q$ & 1 & MAQ & (Yevjevich, 1967) \\
Total Storage Deficit Index & Hydrological & $S n, S S, Q$ & - & TSDI & (Yirdaw et al., 2008) \\
Groundwater Resource Index & Hydrological & $S G$ & - & GRI & (Mendicino et al., 2008) \\
Standardized Runoff Index & Hydrological & $Q$ & $1,3,6,12$ & SRI & (Shukla and Wood, 2008)
\end{tabular}


Hydrol. Earth Syst. Sci. Discuss., https://doi.org/10.5194/hess-2017-512

Manuscript under review for journal Hydrol. Earth Syst. Sci.

Discussion started: 17 August 2017

(c) Author(s) 2017. CC BY 4.0 License.

the SPI-12, SPI-24 and SPEI-12 are classified as meteorological drought indices, however, these are often used as proxy for soil moisture or hydrological drought (Seneviratne et al., 2012). For drought indices that require only precipitation as input, the time series of the WATCH reanalysis dataset were used (Weedon et al., 2011). All indices were derived on a monthly time step and normalized time series for each index were calculated. For more information about the calculation procedure of each drought index the reader is referred to the individual papers mentioned in Table 1 and Wanders et al. (2010).

Indices were evaluated based on the correlations between indices that should indicate similar drought types or could be used to monitor similar impacts (Figure 1). The correlation between two meteorological drought indices (e.g. EDI and SPI-1) is referred to as intrasubstitution. The correlation between indices of different drought types (e.g. SPI-1 for meteorological and GRI for hydrological drought) is referred to as intersubstitution. In addition, the impact of climate types according to in the Köppen-Geiger classification was evaluated, to see if a dependency exist between the correlation and the climate type.

\section{Results}

\subsection{Analysis of spatial patterns in drought indices}

An example of the drought conditions in Africa on August 1984 is shown for all indices under study, to indicate the severity of the drought conditions and to explore difference between drought indices (Figure 3). It is clear that although the 1984 drought in Africa is known to be severe (e.g. Van Huijgevoort et al., 2012; Wada et al., 2013; Masih et al., 2014), not all indices show the dry conditions. There is a strong disagreement among the indices on the drought spatial pattern and the severity. Although not all indices have been developed to monitor the same drought type, similarities in the spatial patterns should be visible between indices of the same drought type. Especially since, most indices of the same type use similar input data. This example of a spatial drought pattern clearly shows that when it was monitored with a single index, the assessment of the natural hazard, could be significantly different from monitoring with another drought index of the same type.

A similar pattern is observed for the 1976 drought in Europe, another severe drought event (Perry, 1976). The extreme conditions for this drought, show large differences between the drought indices (Figure 4). We find extreme dry conditions for the SPEI for large parts of Europe; this could be driven by the strong increases in temperature and hence the strong increase in potential evaporation leading to strong negative values for this index. The inclusion of the potential evapotranspiration is one of the more important differences between the computation of the SPI and SPEI and could clearly explain the spatial differences for Eastern Europe. The SRI tends to follow the behaviour observed for the SPEI, which is interesting since it uses the same input data as the other hydrological indices. Here we see the impact of the standardization that is applied in the computation of the SRI, reducing the impact of the wet conditions for eastern Europe, compared to the other hydrological indices.

\subsection{Analysis of temporal behaviour in drought indices}

30 For a more detailed analysis we have selected a location close to Paris, in the heart of the 1976 drought, were we clearly see that all drought indices pick up on the extreme drought conditions (Figure 5). When we zoom in on the year 1976, we can 
Hydrol. Earth Syst. Sci. Discuss., https://doi.org/10.5194/hess-2017-512 Manuscript under review for journal Hydrol. Earth Syst. Sci.

Discussion started: 17 August 2017

(c) Author(s) 2017. CC BY 4.0 License.
Hydrology and

Earth System

Sciences

Discussions
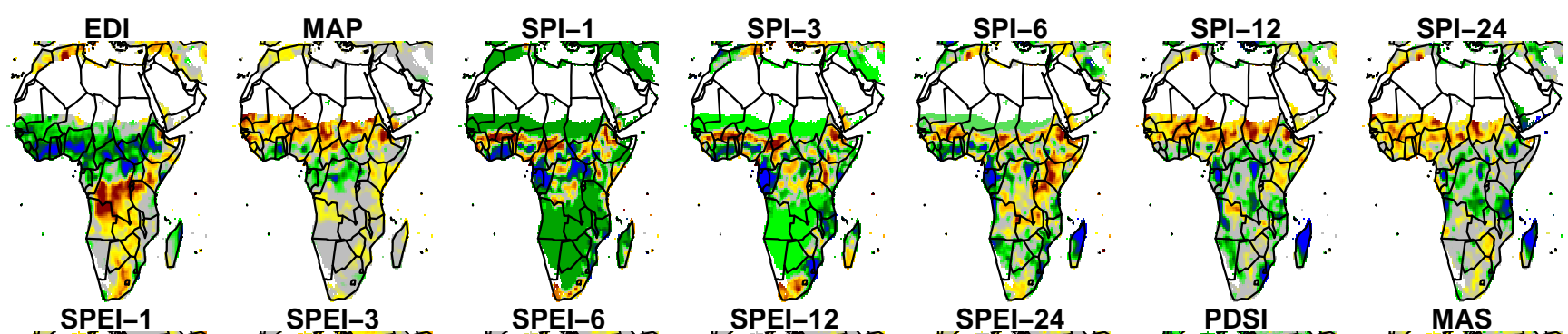

SPEI-6
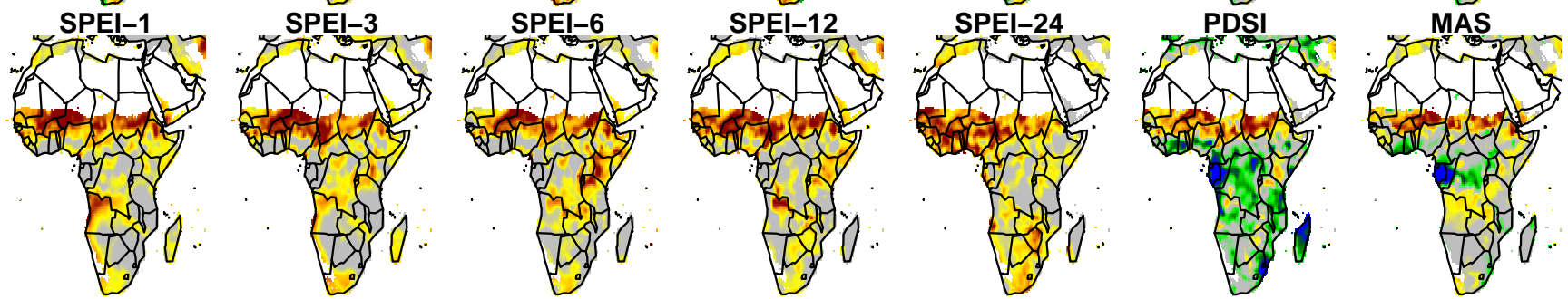

SRI-1
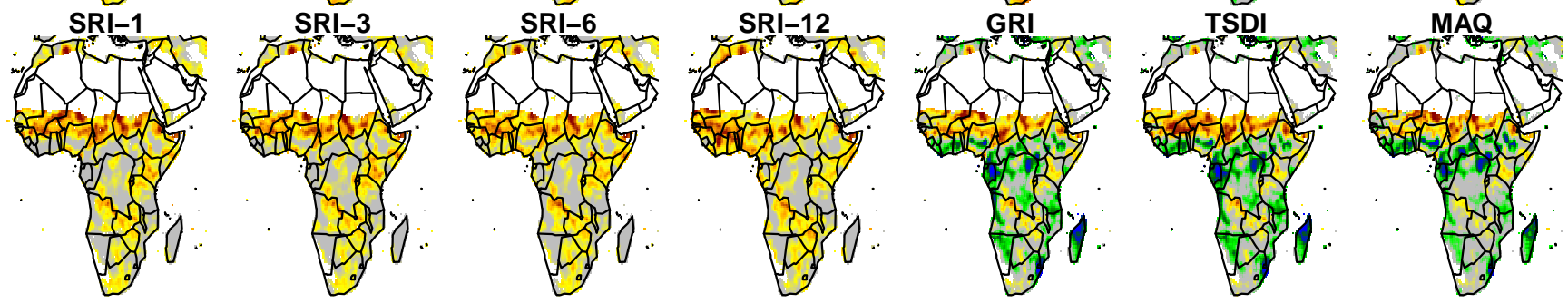

$<-3$

$-2$

1

0

1

2

$>3$

Figure 3. Drought conditions over Africa in August 1984 for selected drought indices under study. Colours indicate the normalized drought severity, where negative values show drought conditions and positive values wetness, and the lower/higher the values the more extreme the drought/wetness.

see clear deviations between the different indices for the onset and termination of the drought conditions. The onset of the drought for the various indices ranges from January to December 1976, with a majority of drought onset around spring/early summer. It is clear that the indices with long aggregation periods (SPI-12, 24, SPEI-12, 24 and SRI-12) show the longest drought duration, with the SPI-24 and SPEI-24 showing a pooling of droughts towards the end of 1977. These indices also show significantly different behaviour with regard to the wet conditions in winter 1974-1975. From Figure 5 it is clear that the difference in aggregation window and calculation method can have a substantial impact on the identification of drought onset and termination in drought simulations or monitoring systems.

\subsection{Intrasubstitution of drought indices}

The correlation between drought indices within a drought type (intrasubstitution, Figure 6) is hypothesised to be high. It is striking to see that meteorological drought was characterized differently by the eleven relevant indices used in this study 
Hydrol. Earth Syst. Sci. Discuss., https://doi.org/10.5194/hess-2017-512 Manuscript under review for journal Hydrol. Earth Syst. Sci.

Discussion started: 17 August 2017

(c) Author(s) 2017. CC BY 4.0 License.
Hydrology and

Earth System

Sciences

Discussions

(c) (i)
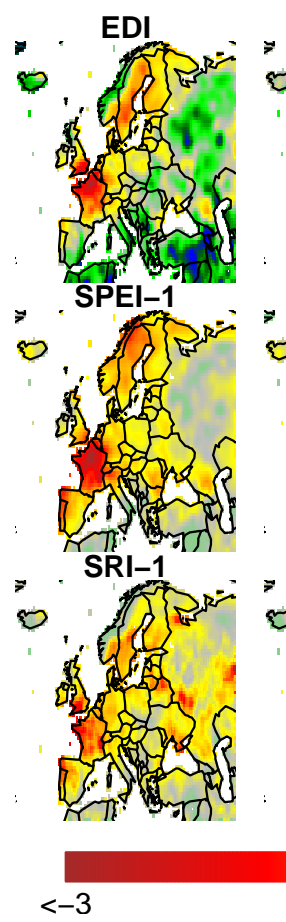
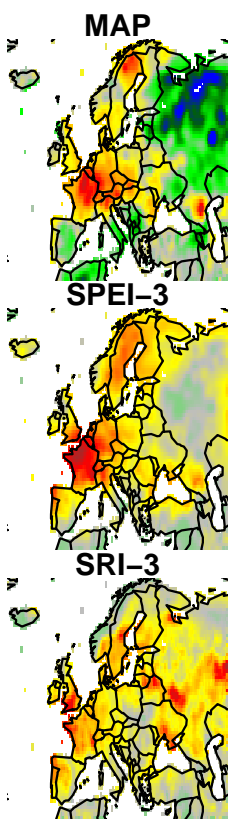

$-2$
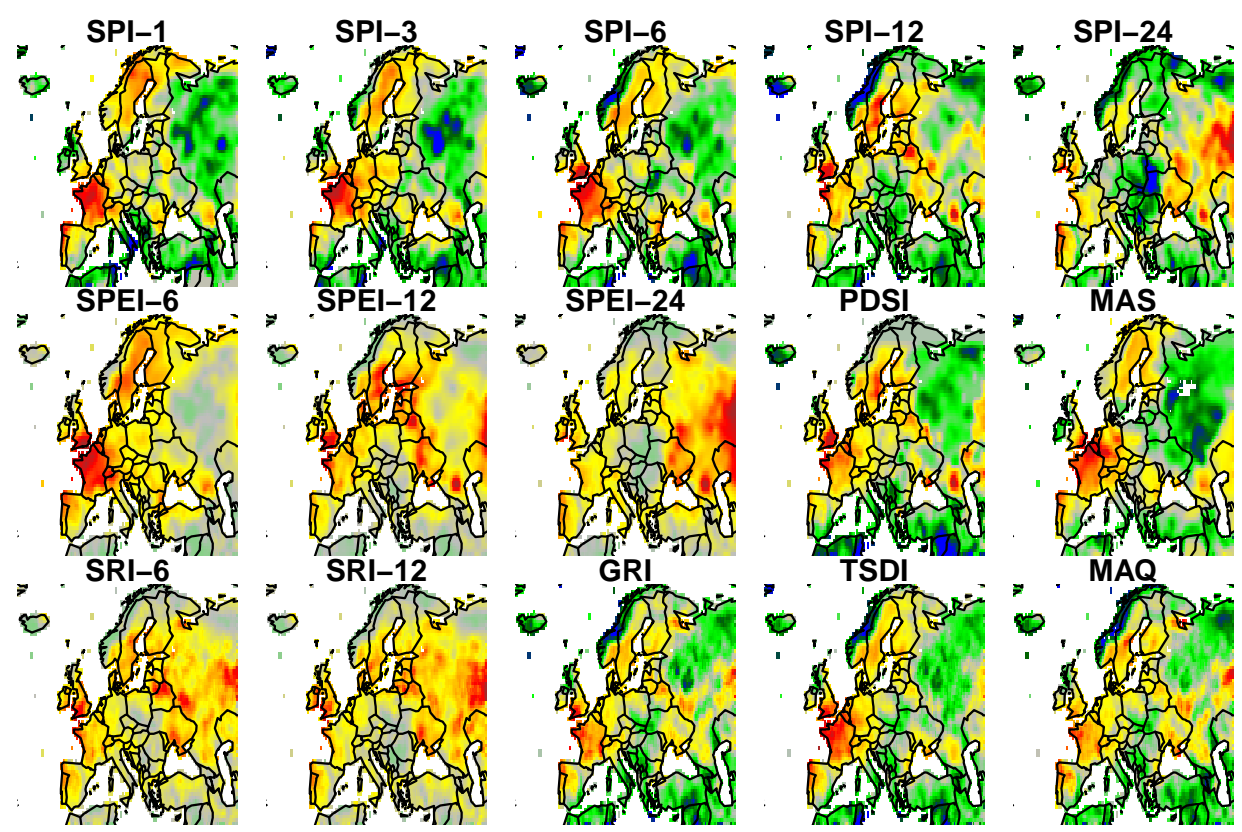

1

2

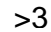

Figure 4. Drought conditions over Europe in August 1976 for selected drought indices under study. Colours indicate the normalized drought severity, where negative values show drought conditions and positive values wetness, and the lower/higher the values the more extreme the drought/wetness.

(EDI, MAP, SPI-1,3,6,12,24, SPEI-1,3,6,12), resulting in the low median correlations over all climates $(R=0.1-0.75)$. An exception is found in the high correlation between SPI and SPEI with similar accumulation periods. Because most of the meteorological indices use only precipitation time series, the cause of any low correlation can fully be allotted to the way in which precipitation time series are transformed to meteorological drought. These indices were expected to have a high correlation because they should represent drought conditions for the same impacts. Any existing differences are largely caused by the way in which index calculations deal with this highly dynamic time series of precipitation, as can be clearly seen from the difference in the SPI and SPEI lag times.

The low average correlations ( $R=0.25$, Figure 6 ) found in the two soil moisture indices (PDSI and MAS) are a result of the different ways in which soil moisture drought is defined. Especially, in situations with snow accumulation (D and $\mathrm{E}$ climate type) the way in which the drought identification was performed is quite important. For example, PDSI does not account for snow or delayed soil moisture availability caused by snow melt, which results in a different drought characteristics compared to MAS.

The intrasubstitution of three hydrological drought indices (SRI-1,3,6,12, GRI, TSDI, MAQ) was high as compared to the other drought types ( $R=0.5-0.98$, Figure 6 , also seen in Figure 3 ). This suggests that one index might already suffice to correctly 
Hydrol. Earth Syst. Sci. Discuss., https://doi.org/10.5194/hess-2017-512

Manuscript under review for journal Hydrol. Earth Syst. Sci.

Discussion started: 17 August 2017

(c) Author(s) 2017. CC BY 4.0 License.
Hydrology and

Earth System

Sciences

Discussions

(c) (i)
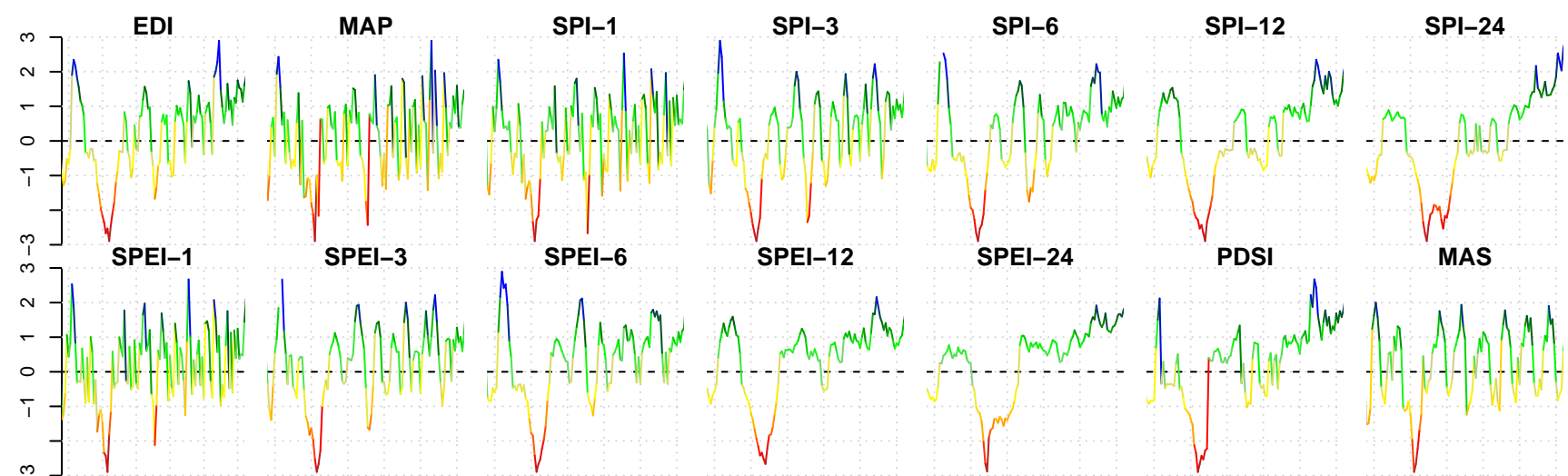

SRI-1 SPEI-3

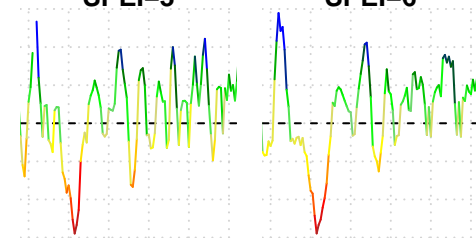

SRI-6
SPEI-24

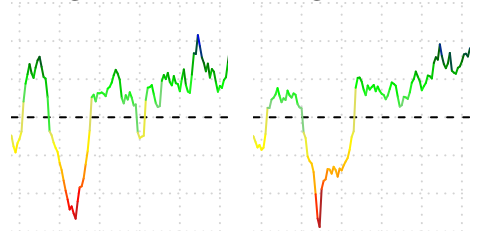

SRI-12

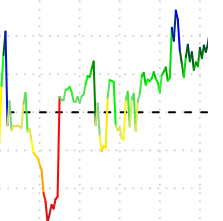

TSDI
MAS

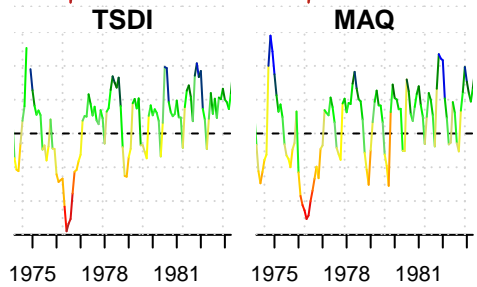

Figure 5. Drought conditions around Paris for the period 1974-1983 for selected drought indices under study. Colours indicate the value of the normalized drought severity, where negative values show drought conditions and positive values wetness, and the lower/higher the values the more extreme the drought/wetness.

characterize hydrological drought events and their impacts (in contrast to meteorological or soil moisture drought). The fact that hydrological drought indices show the highest intrasubstitution could be related to the fact that the dynamics in groundwater and discharge time series is always lower than those of precipitation and soil moisture. This low dynamic behaviour results in a reduced impact of any smoothing or aggregation in the calculation of the drought index leading in consequence to higher correlations and agreement in the identification of drought events. Hydrological drought events often have long duration (Peters et al., 2003), whereas meteorological drought events are often shorter.

\subsection{Intersubstitution of drought indices}

The potential intersubstitution of drought indices is even lower than the intrasubstitution (Section 3.3), which is to be expected when indices are supposed to monitor different parts of the hydrological cycle (Figure 6). Meteorological drought indices show low intersubstitution with soil moisture $(R=0.0-0.6)$ and hydrological drought indices $(R=0.0-0.7)$. The highest correlations of meteorological drought indices with those of other drought types were found for the EDI, SPI-3, SPI-6, SPI-12, SPEI-3, SPEI-6, SPEI-12, while the indices with short or very long aggregation periods (MAP, SPI-1, SPEI-1 and SPI-24), clearly show low potential intersubstitution. The indices with a short aggregation period do not have memory to accurately reproduce soil moisture or hydrological drought conditions. 
Hydrol. Earth Syst. Sci. Discuss., https://doi.org/10.5194/hess-2017-512

Manuscript under review for journal Hydrol. Earth Syst. Sci.

Discussion started: 17 August 2017
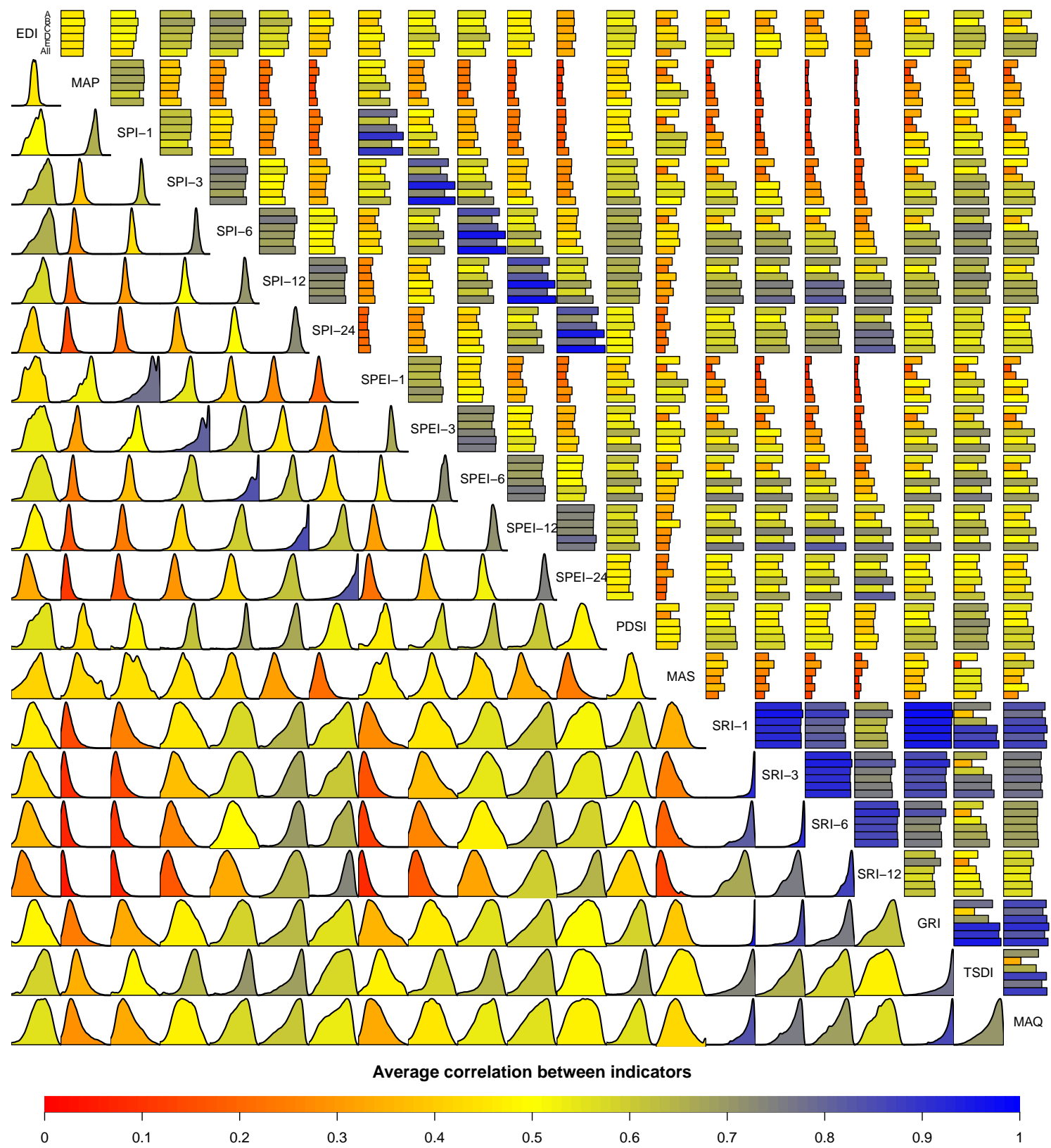

Figure 6. Correlations between indices for the period 1958-2002, where the colours of bars and histograms indicate average correlations between indices. In this cross-correlation diagram, each row and column provide the data of one index, as indicated in the diagonal. Bar plots (above diagonal) indicate the average cross-correlation between index separated for locations with a tropical (A), desert (B), temperate (C), Snow (D), or Polar (E) climate types, and (All) gives the global average (upper left cell gives sequence of climate types for the histograms) For each climate type we have aggregated all the locations that are located in a specific climate type and computed the average cross-correlation. Global cross-correlation distribution (below diagonal) indicates the global average of the correlations where no distinction is made between climate types and the full distribution is provided. The colours of each bar of histogram correspond to the value of the histogram bar (above the diagonal) or the global average cross-correlation (below the diagonal). 
Hydrol. Earth Syst. Sci. Discuss., https://doi.org/10.5194/hess-2017-512

Manuscript under review for journal Hydrol. Earth Syst. Sci.

Discussion started: 17 August 2017

(c) Author(s) 2017. CC BY 4.0 License.

Soil moisture indices show an intermediate intersubstitution with meteorological drought indices $(R=0.0-0.7)$ and hydrological drought indices $(R=0.1-0.65)$, where the PDSI shows the highest intersubstitution with meteorological drought indices.

The results suggest that substitutes (meteorological drought indices that should approximate another drought type), cannot

5 be used to study different drought types. For example, the intersubstitution of drought indices is always lower than the intrasubstitution found for each of the three hydrological drought indices. This indicates, for instance, that differences amongst hydrological drought indices are smaller than differences with possible substitutes, e.g. SPI-12 or SPI-24 ( $R=0.3-0.7)$. Although computational effort and complexity of the calculations might be decreased by selection of a substitute for all drought types, this does not provide useful information for impacted sectors. When the SPI is used to monitor hydrological drought (because of lack of observed discharge data), this leads to different drought severity patterns (see Figure 3).

An impact of snow accumulation is found for the snow-affected (D) and polar (E) climate where the intersubstitution of meteorological and hydrological drought indices is lower than for other climate types. Similar to the result obtained for meteorological drought indices, the intersubstitution between soil moisture and hydrological drought indices is hampered in snow-affected (D) and polar (E) climate regions. This clearly illustrates that snow should be accounted for in these regions, when soil moisture or hydrological drought is considered. In snow affected (D) climates, snowmelt can end drought events by increased water availability in spring, which could lead to different behaviour for indices that either include snow accumulation or not. Moreover, a meteorological drought in winter is not directly visible in groundwater or discharge (Van Loon et al., 2014). Indices that do not include snow accumulation and snow melt are highly affected by this condition and show low correlations in snow-affected regions. In the desert climate (B) all indices are affected by long periods with no precipitation or recharge; for these regions the definition of a drought remains challenging and should be done carefully to avoid a confusion between drought and aridity (i.e. normal climatic conditions). Intersubstitutionality of drought indices is higher in tropical (A) and temperate (C) climate regions than in the dry and cold climates $(\mathrm{B}, \mathrm{D}$ and $\mathrm{E})$.

\subsection{Sensitivity analysis of hydrological model}

To test the sensitivity of the results we have altered the model parameterization to simulate both a coarse sand and sandy loam soil to analyse potential differences in correlation between indices as a results of the model parameterization. In addition, we have altered the groundwater response parameters to reflect a groundwater system that has a $10 \%$ faster or slower response time (Figure 2). From this sensitivity analysis, we see that the parametrization of the conceptual model only has a minor impact on the simulated drought indices and hence it hardly influences the comparison between indices time series. Since for all indices, changes in the parameterization will also result in changes in the drought characterization baseline, the overall impact of the changes in parameterization remains small. We found change in the correlations between drought indices that were less than 0.005 for all indices under study, at all locations. This clearly shows that the impact of the model parametrization on the conclusions of this study is negligible. 
Hydrol. Earth Syst. Sci. Discuss., https://doi.org/10.5194/hess-2017-512

Manuscript under review for journal Hydrol. Earth Syst. Sci.

Discussion started: 17 August 2017

(c) Author(s) 2017. CC BY 4.0 License.

\section{Discussion and Conclusions}

The in general low correlations between drought indices (Figure 6) show that it is very important to select the right physical index for monitoring, forecasting and predicting a drought type relevant for an impacted sector. Since drought impacts are related to different parts of the hydrological cycle (Figure 1), every index provides specific information and hence is viable to monitor drought condition for certain impacts. Additionally, the different spatial patterns between indices for a known drought event show the need to be cautious when using a single drought index to identify specific conditions even for one drought type (Figure 3).

Time series of different drought indices are often used to derive trends in drought characteristics. However, intercomparison of the outcome of these studies should be done with extreme caution since the used indices might capture different drought types, or were computed in different ways leading to differences in the predicted trends (e.g. the PDSI; Dai, 2013; Sheffield et al., 2012). Trend analysis based on a single index creates the illusion that the phenomenon drought is studied in general, but the drought is not captured by one index and consequently only the trend for some impacts is studied. Single index studies can be used to capture trends in a single type of drought (e.g. meteorological or hydrological), although this should also be done with care since using a different index could lead to different results (see intrasubstitution potential, Section 3.3).

We believe that researchers should not try to fulfil this quest to one ultimate drought index, since such an index can never cover the full width of the multi-faced drought phenomenon. Every impact requires a different type of index and although some impacts can be studied with the same physical drought index, this is certainly not a standard procedure (Bachmair et al., 2016a). As was described by Bachmair et al. (2016b) and confirmed in this work, we see that not every index can capture every drought impact. When physical indices are related to drought impacts, it is important to find an index that is as close as possible to the drought impact of interest. In addition we show that the performance of an index is also dependent on climate type, indicating that the desire for one global index certainly cannot be fulfilled.

A distinction can be made between indices used for drought awareness usually on a large scale (e.g. the European Drought Observatory, Sepulcre-Canto et al., 2012) and indices for operational drought management on a river basin scale (e.g. Andreu et al., 2009). We argue that indices for public awareness could be dimensionless and do not require a direct connection with an impacted sector. For example, the SPI with different accumulation periods can be used to monitor anomalies throughout the hydrological cycle, since it gives an indication on the duration and severity of the drought. However, indices like the SPI are not applicable to calculate drought deficits since only standardized anomalies are provided. The SPI or similar indices can be used to increase public drought awareness due to their easy interpretation. Similar calculation procedures as the SPI have been applied to other hydro-meteorological time series to study drought propagation in for example runoff (Standardized Runoff Index, Shukla and Wood, 2008) and groundwater (Standardized Groundwater Index, Bloomfield and Marchant, 2013). For operational purposes, however, a threshold approach would be more suitable, since it can directly be translated into drought deficits, water shortages or storage deficits. The threshold approach is easily applicable throughout the hydrological cycle and therefore suitable for propagation studies (e.g. Peters et al., 2003, 2006; Tallaksen et al., 2009; Van Loon and Van Lanen, 2012; Van Loon et al., 2014). Additionally, the threshold can also be used to study at quantitative changes in drought characteristics 
Hydrol. Earth Syst. Sci. Discuss., https://doi.org/10.5194/hess-2017-512

Manuscript under review for journal Hydrol. Earth Syst. Sci.

Discussion started: 17 August 2017

(c) Author(s) 2017. CC BY 4.0 License.

(c) (i)
Hydrology and

Earth System

Sciences

Discussions

for long historical periods or future projections (e.g. Wanders et al., 2015; Wanders and Wada, 2015). These changes can be directly related to changes in water storage or deficits. The calculated deficits are not meant for the general public unless values are standardised, e.g. by the mean flow.

Results of this study impact the way in which drought should be monitored and forecasted. Since indices are not intrasubsti-

5 tutional, different indices are required for different impacts. Additionally, studying drought in snow-affected regions should be done with more care and a realistic representation of snow accumulation should be included in indices used for these regions (Staudinger et al., 2014). In this study, we show that drought indices show large difference in drought identification and therefore drought indices should be related to the impacted sector under study. Drought indices are hardly intra- and intersubstitutional and therefore a careful selection of the drought index is required. Using a single index to study global trends for all drought types is impossible and unrealistic.

Data availability. The simulated drought index data are available in a Dataverse.nl repository and will be published upon acceptance of the manuscript. The climate type classification has been derived from the Köppen Geiger climate type classifications published at http://hdl.handle.net/10411/OH7MG3

Competing interests. The authors have no competing interests

Acknowledgements. This research was funded by two NWO Rubicon projects (contract number 825.15.003 and 2004/08338/ALW). It also contributed to the European Union funded FP7 and H2020 projects DROUGHT-R\&SPI (contract no. 282769) and ANYWHERE (contract no. 700099). It is part of the programme of the Wageningen Institute for Environment and Climate Research (WIMEK-SENSE) and it supports the work of the UNESCO-IHP VIII FRIEND-Water programme and the IAHS Panta Rhei decade. 
Hydrol. Earth Syst. Sci. Discuss., https://doi.org/10.5194/hess-2017-512

Manuscript under review for journal Hydrol. Earth Syst. Sci.

Discussion started: 17 August 2017

\section{References}

Andreu, J., Ferrer-Polo, J., Pérez, M., and Solera, A.: Decision Support System for Drought Planning and Management in the Jucar River Basin, Spain, in: 18 th World IMACS/MODSIM Congress, Cairns, Australia, 2009.

Bachmair, S., Stahl, K., Collins, K., Hannaford, J., Acreman, M., Svoboda, M., Knutson, C., Smith, K. H., Wall, N., Fuchs, B., Crossman, N. D., and Overton, I. C.: Drought indicators revisited: the need for a wider consideration of environment and society, Wiley Interdisciplinary Reviews: Water, 3, 516-536, 2016a.

Bachmair, S., Svensson, C., Hannaford, J., Barker, L. J., and Stahl, K.: A quantitative analysis to objectively appraise drought indicators and model drought impacts, Hydrology and Earth System Sciences, 20, 2589-2609, doi:10.5194/hess-20-2589-2016, 2016b.

Blauhut, V., Gudmundsson, L., and Stahl, K.: Towards pan-European drought risk maps: quantifying the link between drought indices and reported drought impacts, Environmental Research Letters, 10, 014 008, doi:10.1088/1748-9326/10/1/014008, 2015.

Blauhut, V., Stahl, K., Stagge, J. H., Tallaksen, L. M., De Stefano, L., and Vogt, J.: Estimating drought risk across Europe from reported drought impacts, drought indices, and vulnerability factors, Hydrology and Earth System Sciences, 20, 2779-2800, 2016.

Bloomfield, J. P. and Marchant, B. P.: Analysis of groundwater drought building on the standardised precipitation index approach, Hydrology and Earth System Sciences, 17, 4769-4787, doi:10.5194/hess-17-4769-2013, 2013.

Byun, H. and Wilhite, D.: Objective quantification of drought severity and duration, Bulletin of the American Meteorological Society, 12, $2747-2756,1999$.

Dai, A.: Increasing drought under global warming in observations and models, Nature Climate Change, 3, 52-58, doi:10.1038/nclimate1633, 2013.

Gudmundsson, L., Rego, F. C., Rocha, M., and Seneviratne, S. I.: Predicting above normal wildfire activity in southern Europe as a function of meteorological drought, Environmental Research Letters, 9, 084 008, 2014.

Howitt, R., Medellín-Azuara, J., MacEwan, D., Lund, J., and Sumner, D.: Economic Analysis of the 2014 Drought for California Agriculture, Report of UC Davis, Center for Watershed Sciences, 2014.

Howitt, R., MacEwan, D., Medellín-Azuara, J., Lund, J., and Sumner, D.: Economic Analysis of the 2015 Drought for California Agriculture, Report of UC Davis, Center for Watershed Sciences, 2015.

Keyantash, J. and Dracup, J.: The quantification of drought: An evaluation of drought indices, Bulletin of the American Meteorological Society, 83, $1167-1180,2002$.

Masih, I., Maskey, S., Mussá, F. E. F., and Trambauer, P.: A review of droughts on the African continent: a geospatial and long-term perspective, Hydrology and Earth System Sciences, 18, 3635-3649, doi:10.5194/hess-18-3635-2014, 2014.

McKee, T., Doesken, N., and Kleist, J.: The relationship of drought frequency and duration to time scales, in: Eighth Conference on Applied Climatology, 17-22 January, Anaheim, California, 1993.

Medellín-Azuara, J., MacEwan, D., Howitt, R., Sumner, D., and Lund, J.: Economic Analysis of the 2016 Drought for California Agriculture, Report of UC Davis, Center for Watershed Sciences, 2016.

Mendicino, G., Senatore, A., and Versace, P.: A Groundwater Resource Index for drought monitoring and forecasting in a mediterranean climate, Journal of Hydrology, 357, 282 - 302, 2008.

Mishra, A. K. and Singh, V. P.: A review of drought concepts, Journal of Hydrology, 391, 202 - 216, doi:10.1016/j.jhydrol.2010.07.012, 2010.

Palmer, W.: Meteorological drought, U.S. Weather Bureau Research Paper, No. 45, 58 pp, 1965. 
Hydrol. Earth Syst. Sci. Discuss., https://doi.org/10.5194/hess-2017-512

Manuscript under review for journal Hydrol. Earth Syst. Sci.

Discussion started: 17 August 2017

Pedro-Monzonía, M., Solera, A., Ferrer, J., Estrela, T., and Paredes-Arquiola, J.: A review of water scarcity and drought indexes in water resources planning and management, Journal of Hydrology, 527, 482-493, 2015.

Perry, A. H.: The long drought of 1975-76, Weather, 31, 328-336, doi:10.1002/j.1477-8696.1976.tb07448.x, 1976.

Peters, E., Torfs, P. J. J. F., van Lanen, H. A. J., and Bier, G.: Propagation of drought through groundwater - a new approach using linear reservoir theory, Hydrological Processes, 17, 3023 - 3040, 2003.

Peters, E., Bier, G., van Lanen, H. A. J., and Torfs, P. J. J. F.: Propagation and spatial distribution of drought in a groundwater catchment, Journal of Hydrology, 321, 257 - 275, doi:10.1016/j.jhydrol.2005.08.004, 2006.

Seneviratne, S. I., Nicholls, N., Easterling, D., Goodess, C. M., Kanae, S., Kossin, J., Luo, Y., Marengo, J., McInnes, K., Rahimi, M., Reichstein, M., Sorteberg, A., Vera, C., and Zhang, X.: Changes in climate extremes and their impacts on the natural physical environment, chap. A Special Report of Working Groups I and II of the Intergovernmental Panel on Climate Change (IPCC), pp. 109-230, Cambridge University Press, Cambridge, UK, and New York, NY, USA, 2012.

Sepulcre-Canto, G., Horion, S., Singleton, A., Carrao, H., and Vogt, J.: Development of a Combined Drought Indicator to detect agricultural drought in Europe, Natural Hazards and Earth System Science, 12, 3519-3531, doi:10.5194/nhess-12-3519-2012, 2012.

Sheffield, J. and Wood, E. F.: Drought: Past Problems and Future Scenarios, Earthscan, London, 2011.

Sheffield, J., Wood, E. F., and Roderick, M. L.: Little change in global drought over the past 60 years, Nature, 491, 435-438, doi:10.1038/nature11575, 2012.

Shukla, S. and Wood, A. W.: Use of a standardized runoff index for characterizing hydrologic drought, Geophysical Research Letters, 35 , L02 405, doi:10.1029/2007GL032487, 2008.

Stagge, J. H., Kohn, I., Tallaksen, L. M., and Stahl, K.: Modeling drought impact occurrence based on meteorological drought indices in Europe, Journal of Hydrology, 530, 37 - 50, doi:10.1016/j.jhydrol.2015.09.039, 2015.

Staudinger, M., Stahl, K., and Seibert, J.: A drought index accounting for snow, Water Resources Research, 50, 7861-7872, doi:10.1002/2013WR015143, 2014.

Tallaksen, L. M. and Van Lanen, H. A. J.: Hydrological Drought: Processes and estimation methods for streamflow and groundwater, no. 48 in Development in water science, Elsevier, 2004.

Tallaksen, L. M., Hisdal, H., and Van Lanen, H. A. J.: Space-time modelling of catchment scale drought characteristics, Journal of Hydrology, $375,363-372,2009$.

Taufik, M., Torfs, P. J. J. F., Uijlenhoet, R., Jones, P. D., Murdiyarso, D., and Van Lanen, H. A. J.: Amplification of wildfire area burnt by hydrological drought in the humid tropics, Nature Climate Change, 7, 428-431, 2017.

Van Huijgevoort, M. H. J., Hazenberg, P., Van Lanen, H. A. J., and Uijlenhoet, R.: A generic method for hydrological drought identification across different climate regions, Hydrology and Earth System Sciences, 16, 2437-2451, doi:10.5194/hess-16-2437-2012, 2012.

Van Lanen, H.: Drought: How to be Prepared for the Hazard?, pp. 171-201, John Wiley \& Sons, Ltd, doi:10.1002/9781118629567.ch3b, 2014.

Van Lanen, H. A. J., Wanders, N., Tallaksen, L. M., and Van Loon, A. F.: Hydrological drought across the world: impact of climate and physical catchment structure, Hydrology and Earth System Sciences, 17, 1715-1732, doi:10.5194/hess-17-1715-2013, 2013.

Van Loon, A. F. and Van Lanen, H. A. J.: A process-based typology of hydrological drought, Hydrology and Earth System Sciences, 16, 1915-1946, doi:10.5194/hess-16-1915-2012, 2012.

Van Loon, A. F., Tijdeman, E., Wanders, N., Van Lanen, H. A. J., Teuling, A. J., and Uijlenhoet, R.: How Climate Seasonality Modifies Drought Duration and Deficit, Journal of Geophysical Research: Atmospheres, 119, 4640-4656, doi:10.1002/2013JD020383, 2014. 
Hydrol. Earth Syst. Sci. Discuss., https://doi.org/10.5194/hess-2017-512

Manuscript under review for journal Hydrol. Earth Syst. Sci.

Discussion started: 17 August 2017

(c) Author(s) 2017. CC BY 4.0 License.

(c) (i)
Hydrology and

Earth System

Sciences

Discussions

Vicente-Serrano, S. M., Beguería, S., and López-Moreno, J. I.: A Multiscalar Drought Index Sensitive to Global Warming: The Standardized

Precipitation Evapotranspiration Index, Journal of Climate, 23, 1696-1718, doi:10.1175/2009JCLI2909.1, 2009.

Wada, Y., van Beek, L. P. H., Wanders, N., and Bierkens, M. F. P.: Human water consumption intensifies hydrological drought worldwide, Environmental Research Letters, 8, 034 036, doi:10.1088/1748-9326/8/3/034036, 2013.

5 Wanders, N. and Van Lanen, H. A. J.: Future discharge drought across climate regions around the world modelled with a synthetic hydrological modelling approach forced by three general circulation models, Natural Hazards and Earth System Sciences, 15, 487-504, doi:10.5194/nhess-15-487-2015, 2015.

Wanders, N. and Wada, Y.: Human and climate impacts on the 21st century hydrological drought, Journal of Hydrology, pp. 1-13, doi:10.1016/j.jhydrol.2014.10.047, 2015.

Wanders, N., Van Lanen, H. A. J., and Van Loon, A. F.: Indicators for drought characterization on a global scale., Tech. Rep. 24, EU-WATCH, 2010.

Wanders, N., Wada, Y., and Van Lanen, H. A. J.: Global hydrological droughts in the 21 st century under a changing hydrological regime, Earth System Dynamics, 6, 1-15, doi:10.5194/esd-6-1-2015, 2015.

Weedon, G. P., Gomes, S., Viterbo, P., Shuttleworth, W. J., Blyth, E., Ã-sterle, H., Adam, J. C., Bellouin, N., Boucher, O., and Best, M.:

Creation of the WATCH Forcing Data and Its Use to Assess Global and Regional Reference Crop Evaporation over Land during the Twentieth Century, Journal of Hydrometeorology, 12, 823-848, doi:10.1175/2011JHM1369.1, 2011.

Wilhite, D.: Drought: A global assessment, Routledge, 2000.

Wilhite, D. A. and Glantz, M. H.: Understanding: the Drought Phenomenon: The Role of Definitions, Water International, 10, 111-120, doi:10.1080/02508068508686328, 1985.

World Meteorological Organization: Experts agree on a universal drought index to cope with climate risks, Press release No. 872, 2009.

Yevjevich, V.: An objective approach to definition and investigation of continental hydrological droughts, Hydrology papers, 23, Colorado state university, Fort Collins, USA, 1967.

Yirdaw, S., Snelgrove, K., and Agboma, C.: GRACE satellite observations of terrestrial moisture changes for drought characterization in the Canadian Prairie, Journal of Hydrology, 356, 84 - 92, 2008. 